\title{
Influence of cultivation system and forecrop on colonization by fungi of the genus Fusarium and mycotoxin content in grain of spring wheat
}

\author{
Wpływ systemu uprawy i przedplonu na zasiedlenie ziarna przez grzyby \\ rodzaju Fusarium i zawartość mikotoksyn w ziarnie pszenicy jarej
}

\author{
Joanna Horoszkiewicz-Janka*, Ewa Jajor, Katarzyna Pieczul
}

\begin{abstract}
Summary
Cereal grain colonization by pathogenic fungi is affected among other things by availability of pathogen inoculum, weather conditions during plant vegetation and employed cultivation systems. The aim of the study was to determine influence of cultivation method and forecrop on colonization of wheat grain by fungi of the genus Fusarium, and to assess the content of mycotoxins in collected grain. The experiment was carried out in the years 2012 and 2013 in the fields of the Field Experimental Station of the Institute of Plant Protection of the National Research Institute in Winna Góra. Spring wheat cultivar Żura was sown after four different forecrops: rape, beet, corn and wheat. Soil was prepared for the experiments with the traditional and reduced tillage system. During vegetation, wheat crop was protected with fungicides applied at different stages of plant development. The wheat grain collected in the experiments was placed on potato-dextrose-agar (PDA) medium to determine grain colonization by pathogenic fungi. The content of mycotoxins: deoxynivalenol (DON) and zearalenone (ZEA) in flour obtained from the collected grain was assessed with the ELISA method. The greatest colonization of spring wheat grain by fungi of the genus Fusarium in the both years of the research was observed in cultivation after beet. The content of deoxynivalenol and zearalenone in all the examined samples did not exceed the European Union maximum acceptable levels of mycotoxins in cereal products.
\end{abstract}

Key words: spring wheat; cultivation system; grain; fungi; mycotoxins

\section{Streszczenie}

Na zasiedlenie ziarna zbóż przez grzyby chorobotwórcze wpływają między innymi: dostępność inokulum patogena, warunki atmosferyczne $w$ trakcie wegetacji roślin oraz stosowane systemy uprawy. Celem badania było określenie wpływu sposobu uprawy oraz przedplonu na zasiedlenie ziarna pszenicy przez grzyby rodzaju Fusarium oraz określenie zawartości mikotoksyn w zebranym ziarnie. Doświadczenie prowadzono w latach 2012 i 2013 na polach Polowej Stacji Doświadczalnej Instytutu Ochrony Roślin Państwowego Instytutu Badawczego w Winnej Górze. Pszenicę jarą odmiany Żura wysiewano po czterech różnych przedplonach: rzepaku, buraku, kukurydzy i pszenicy z zastosowaniem zabiegów uprawowych zgodnych z systemami: tradycyjnym i uproszczonym. W trakcie wegetacji pszenicę chroniono fungicydami w różnych fazach rozwojowych. Zebrane z doświadczeń ziarno pszenicy wykładano na pożywkę agarozowo-glukozowo-ziemniaczaną (PDA - Potato Dextrose Agar) w celu określenia jego zasiedlenia przez chorobotwórcze grzyby. Zawartość mikotoksyn: deoksyniwalenolu (DON) i zearalenonu (ZEA) w mące uzyskanej z zebranego ziarna oznaczano z zastosowaniem testu ELISA. Największe zasiedlenie ziarna pszenicy jarej przez grzyby rodzaju Fusarium w obydwu latach badań stwierdzono w uprawie po burakach. Zawartość deoksyniwalenolu i zearalenonu we wszystkich badanych próbach nie przekraczała dopuszczalnych przez Unię Europejską norm dotyczących ilości mikotoksyn w produktach zbożowych.

Słowa kluczowe: pszenica jara; systemy uprawy; ziarno; grzyby; mikotoksyny

Instytut Ochrony Roślin - Państwowy Instytut Badawczy

Zakład Mikologii

Władysława Węgorka 20, 60-318 Poznań

*corresponding author: j.horoszkiewicz@iorpib.poznan.pl 


\section{Wstęp / Introduction}

W Europie fuzarioza kłosów powodowana jest głównie przez Fusarium graminearum Schwabe i Fusarium culmorum (WG Smith) (Bottalico i Perrone 2002; Popiel i wsp. 2008; Prodi i wsp. 2009). Duży udział zbóż w płodozmianie zwiększa ryzyko porażenia roślin przez liczne grzyby chorobotwórcze, zwłaszcza rodzaju Fusarium (Korbas i wsp. 2008). Grzyby te rozwijają się na resztkach pożniwnych oraz znajdują się w glebie. Zastosowanie uproszczonych systemów uprawy powoduje słabsze przykrycie glebą resztek pożniwnych, co wydłuża ich mineralizację i stwarza możliwość dalszego rozwoju grzybów (Kotowicz i wsp. 2014). Patogen może przezimować $\mathrm{w}$ resztkach pożniwnych roślin w postaci grzybni lub chlamydospor. Wiosną tworzące się w sporodochiach makrokonidia rozprzestrzeniają się $\mathrm{z}$ kroplami deszczu przez rozchlapywanie (Kryczyński i Weber 2011). Grzyby tego rodzaju stanowią potencjalne zagrożenie dla uzyskania wysokich plonów o dobrej jakości. Niebezpieczne dla zdrowia ludzi i zwierząt są metabolity (mikotoksyny) wytwarzane przez grzyby rodzaju Fusarium. Najczęściej spotykanymi w Europie mikotoksynami, które są wytwarzane przez grzyby powodujące fuzariozę kłosów są deoksyniwalenol i zearalenon (Bottalico i Perrone 2002). Zasiedlenie ziarna przez te grzyby może spowodować przekroczenie dopuszczalnych norm zawartości wymienionych mikotoksyn wyznaczonych przez Unię Europejską (UE) (Rozporządzenie 2006, 2007). W celu ograniczania występowania fuzariozy kłosów, a zarazem mikotoksyn, w fazie kwitnienia zaleca sie stosować fungicydy (Stępień i Chełkowski 2010). W programach ochrony roślin zarejestrowanych jest dużo fungicydów do ograniczania fuzariozy kłosów. Jednak nie zawsze ich zastosowanie powoduje zmniejszenie porażenia ziarna przez grzyby i zawartości mikotoksyn.

Celem badań było określenie wpływu sposobu uprawy oraz przedplonu na zasiedlenie ziarna pszenicy jarej przez grzyby rodzaju Fusarium oraz występowanie w nim mikotoksyn.

\section{Materiały i metody / Materials and methods}

\section{Badania polowe}

Badania prowadzono na terenie Polowej Stacji Doświadczalnej Instytutu Ochrony Roślin - Państwowego Instytutu Badawczego (PSD IOR - PIB) w Winnej Górze w latach 2012-2013. W doświadczeniach użyto ziarno pszenicy jarej odmiany Żura. Pszenicę wysiewano po czterech różnych przedplonach: rzepaku, buraku, kukurydzy i pszenicy. Zabiegi uprawowe wykonywano systemem tradycyjnym (podorywka, bronowanie, później orka, bronowanie i tradycyjny siew) oraz uproszczonym (brona, brona talerzowa $\mathrm{z}$ wałem $\mathrm{i}$ siew). W trakcie wegetacji pszenicę chroniono fungicydami w różnych terminach: kombinacja kontrolna - ziarno zaprawione, kombinacja 2 - ziarno zaprawione, zabieg z użyciem fungicydu w terminie T1 (BBCH 30-31), kombinacja 3 ziarno zaprawione, zabiegi z użyciem fungicydów w terminach T1 (BBCH 30-31), T2 (BBCH 49) i T3 (BBCH 56) (tab. 1). Doświadczenie założono w 4 powtórzeniach do zbioru.

\section{Ocena zasiedlenia ziarna przez grzyby}

W celu określenia zasiedlenia ziarna przez grzyby rodzaju Fusarium na pożywkę agarowo-glukozowoziemniaczaną (PDA - Potato Dextrose Agar) wykładano z każdej kombinacji po 300 ziarniaków zebranych z trzech powtórzeń doświadczenia polowego (po 100 ziarniaków z poletka). Materiał do badań odkażano przez 2,5 minuty w $1 \% \mathrm{NaOCl}$ i trzykrotnie płukano w sterylnej wodzie destylowanej. Gatunki grzybów oznaczano na podstawie charakterystycznych makro- i mikroskopowych cech kultur.

\section{Oznaczanie mikotoksyn}

Do badań mikotoksyn przygotowano próbki zbiorcze dla każdej z kombinacji poprzez wymieszanie z każdego z 4 powtórzeń po 50 gramów ziarna. Z tak przygotowanych próbek pobrano 50 gramów i zmielono młynkiem AKA - analytical mill. Zawartość deoksyniwalenolu (DON) i zearalenonu (ZEA) w zmielonych próbach ziarna oznaczano metodą immunoenzymatyczną ELISA przy użyciu testów Veratox DON HS, DON 5/5 i ZEA (firmy Neogen) według procedury producenta. Do odczytu reakcji wykorzystywano fotometr Stat Fax 303 Plus.

Uzyskane wyniki dotyczące procentowego udziału grup grzybów poddano analizie statystycznej wykonując analizę wariancji, najmniejszą istotną różnicę NIR obliczono dla poziomu ufności $\alpha=0,05$ za pomocą testu t-Studenta.

\section{Wyniki i dyskusja / Results and discussion}

Spośród grzybów patogenicznych izolowano następujące gatunki Fusarium: F. culmorum, F. tricinctum, F. graminearum, $F$. poae, $F$. avenaceum i Helminthosporium sativum. Najliczniej stwierdzano występowanie $F$. poae,

Tabela 1. Schemat ochrony przy użyciu fungicydów

Table 1. Schedule of fungicide protection

\begin{tabular}{|c|c|c|c|}
\hline $\begin{array}{c}\text { Termin zabiegu } \\
\text { Date of application }\end{array}$ & $\begin{array}{l}\text { Fungicyd } \\
\text { Fungicide }\end{array}$ & $\begin{array}{c}\text { Substancja czynna i jej zawartość } \\
\text { Active substance and its content } \\
{[\mathrm{g} / \mathrm{l}]}\end{array}$ & $\begin{array}{c}\text { Dawka } \\
\text { Dose } \\
{[1 / \text { ha }]}\end{array}$ \\
\hline $\mathrm{T} 1-\mathrm{BBCH} 31-32$ & Duett Ultra 497 SC & tiofanat metylowy [310], epoksykonazol [187] & 0,6 \\
\hline $\mathrm{T} 2-\mathrm{BBCH} 49$ & Sparta $250 \mathrm{EW}$ & tebukonazol [250] & 1,0 \\
\hline T3- BBCH 56 & Tango Star 334 SE & fenpropimorf [250], epoksykonazol [84] & 1,0 \\
\hline
\end{tabular}


a w drugiej kolejności $F$. tricinctum. Lenc (2015) również najczęściej izolował $F$. poae $\mathrm{z}$ ziarniaków z różnych systemów uprawy pszenicy ozimej. W ziarniakach zebranych w 2012 roku największe występowanie grzybów rodzaju Fusarium stwierdzono w kombinacji z zastosowaniem uproszczonej uprawy pszenicy po buraku $(24 \%$ w kombinacji kontrolnej i 34\% w kombinacji, w której wykonano zabieg w terminie T1) oraz przy uprawie tradycyjnej po buraku $(24 \%$ zarówno $\mathrm{z}$ kombinacji kontrolnej, jak i z kombinacji, w której wykonano zabieg w terminie T1) (tab. 3). Większe porażenie przez grzyby rodzaju Fusarium pszenicy uprawianej po buraku mogło być związane ze zwiększonym porażeniem buraków cukrowych przez te grzyby. W 2013 roku stwierdzono mniejsze, niż w poprzednim sezonie, zasiedlenie ziarna pszenicy jarej przez grzyby patogeniczne. Analogicznie do roku poprzedniego najwięcej grzybów rodzaju Fusarium wyizolowano $\mathrm{z}$ ziarna pszenicy uprawianej po buraku, w systemie tradycyjnym, w którym przeprowadzono 3 zabiegi fungicydowe - 16\% (tab. 3). W badaniach przeprowadzonych w Niemczech i Szwajcarii, w niektórych latach i rejonach, również stwierdzono wzrost występowania fuzariozy kłosów pszenicy uprawianej po burakach cukrowych (Lienemann 2002; Hecker i wsp. 2009). W badaniach Christa i wsp. (2011) stwierdzono porażanie pszenicy jarej przez izolaty $F$. graminearum, $F$. culmorum, $F$. cerealis, $F$. tricinctum i $F$. equiseti pochodzące $\mathrm{z}$ buraków cukrowych. Większe zasiedlenie przez grzyby rodzaju Fusarium ziarna pszenicy jarej zebranego w 2012 roku niż w 2013 roku spowodowane było obfitymi opadami w czerwcu i lipcu, które wynosiły ponad $90 \mathrm{~mm}$ (rys. 1). Znaczne opady deszczu notowano również w 2013 roku (ponad $80 \mathrm{~mm}$ ), ale wystąpiły one wcześniej, tj. w maju i czerwcu.

W badaniach własnych zasiedlenie ziarna przez grzyby patogeniczne $\mathrm{W}$ zależności od systemu uprawy było statystycznie niższe w tradycyjnym systemie (średnio 7,9\%) aniżeli w systemie uproszczonym (średnio 10,5\%) (tab. 2). W badaniach Lenca i wsp. (2009) zasiedlenie ziarna przez grzyby rodzaju Fusarium pochodzącego z tradycyjnego i uproszczonego systemu uprawy było na zbliżonym poziomie. Największy procent kolonii grzybów wyizolowanych $\mathrm{z}$ ziarniaków pszenicy jarej stanowiły saprotrofy, przede wszystkim gatunki rodzaju Alternaria. Często występowały również: Epicoccum purpurescens, Cladosporium herbarum i Botrytis cinerea. Z ziaren pszenicy izolowano również grzyby niezarodnikujące oraz niewielką liczbę bakterii - tylko w 2013 roku, lecz nie uwzględniono ich w niniejszej pracy. Średnio dla obydwu lat najmniejszą liczbę saprotrofów wyizolowano z ziarna pszenicy uprawianej po buraku - 82,5 (tab. 2). W zależności od systemu uprawy oraz stosowanej w trakcie wegetacji ochrony fungicydowej nie stwierdzono istotnych różnic $\mathrm{w}$ występowaniu saprotrofów dla średnich $\mathrm{z}$ lat.

$\mathrm{W}$ większości kombinacji, w których stosowano trzy zabiegi z użyciem fungicydów zaobserwowano tendencję do zmniejszenia zasiedlenia ziarna pszenicy przez grzyby patogeniczne. Zostało to potwierdzone statystycznie tylko w pierwszym roku badań (tab. 2).

Ochrona pszenicy, jęczmienia, pszenżyta i żyta przed fuzariozą kłosów jest możliwa przy użyciu zarejestrowanych fungicydów. Zastosowanie fungicydu nie zawsze ogranicza zawartości mikotoksyn w ziarnie (Mesterházy i wsp. 2003). W badaniach Mesterházy i wsp. (2003) $\mathrm{w}$ jednym $\mathrm{z}$ sezonów $\mathrm{w}$ wyniku zastosowania fungicydu zawierającego azoksystrobinę, $w$ porównaniu $\mathrm{z}$ innymi zastosowanymi fungicydami, stwierdzono zwiększoną zawartość deoksyniwalenolu w ziarnie pszenicy ozimej. W badaniach Czabana i wsp. (2011) wykazano najsilniejsze porażenie przez Fusarium spp. kłosów pszenicy ozimej oraz zasiedlenie przez te grzyby w intensywnej technologii uprawy.

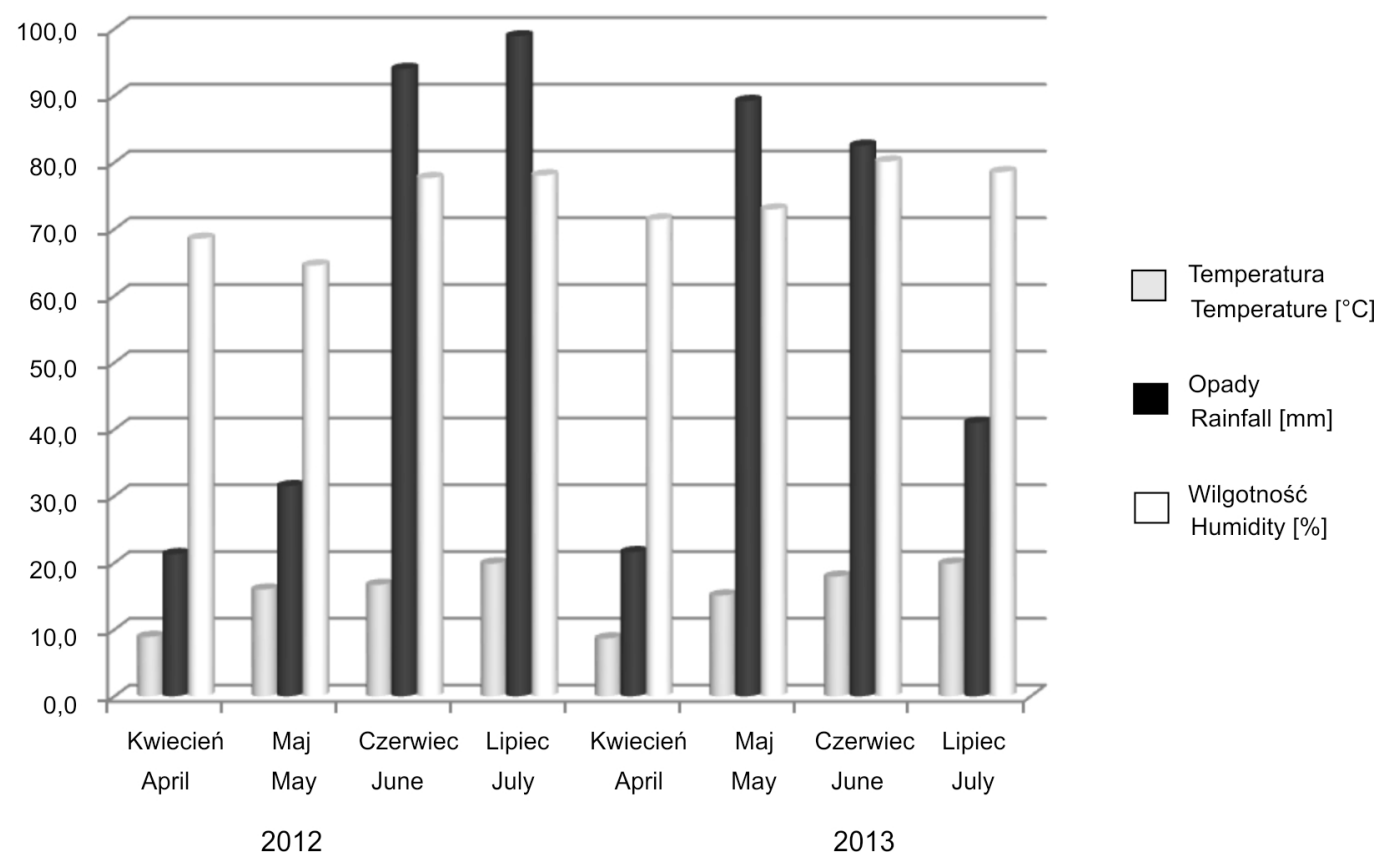

Rys. 1. Charakterystyka warunków pogodowych w sezonach 2012 i 2013

Fig. 1. Weather conditions in the seasons 2012 and 2013 
Tabela 2. Procentowy udział grup grzybów zasiedlających ziarno pszenicy jarej

Table 2. Percentage share of fungi present in the grain of spring wheat

\begin{tabular}{|c|c|c|c|c|c|c|c|}
\hline \multirow{2}{*}{\multicolumn{2}{|c|}{$\begin{array}{c}\text { Czynnik } \\
\text { Factor }\end{array}$}} & \multicolumn{3}{|c|}{ Saprotrofy - Saprotrophic } & \multicolumn{3}{|c|}{ Patogeny - Pathogenic } \\
\hline & & \multirow{2}{*}{$\begin{array}{l}2012 \\
84,6\end{array}$} & \multirow{2}{*}{$\begin{array}{l}2013 \\
92,7\end{array}$} & \multirow{2}{*}{$\begin{array}{c}\begin{array}{c}\text { średnia } \\
\text { mean }\end{array} \\
88,7\end{array}$} & \multirow{2}{*}{$\begin{array}{c}2012 \\
10,3\end{array}$} & \multirow{2}{*}{$\begin{array}{r}2013 \\
4,0\end{array}$} & \multirow{2}{*}{$\begin{array}{c}\begin{array}{c}\text { średnia } \\
\text { mean }\end{array} \\
7,2\end{array}$} \\
\hline \multirow{4}{*}{$\begin{array}{l}\text { Przedplon } \\
\text { Forecrop }\end{array}$} & $\begin{array}{l}\text { pszenica } \\
\text { wheat }\end{array}$ & & & & & & \\
\hline & $\begin{array}{l}\text { kukurydza } \\
\text { corn }\end{array}$ & 82,0 & 90,2 & 86,1 & 11,7 & 5,0 & 8,3 \\
\hline & $\begin{array}{l}\text { rzepak } \\
\text { rape }\end{array}$ & 84,3 & 91,7 & 88,0 & 9,3 & 4,3 & 6,8 \\
\hline & $\begin{array}{c}\text { burak } \\
\text { beet }\end{array}$ & 76,3 & 88,7 & 82,5 & 21,7 & 7,3 & 14,5 \\
\hline \multicolumn{2}{|c|}{$\operatorname{NIR}(0,05)-\operatorname{LSD}(0.05)$} & 3,917 & 2,667 & 2,200 & 2,575 & 1,704 & 1,433 \\
\hline \multirow{2}{*}{$\begin{array}{l}\text { System uprawy } \\
\text { The method } \\
\text { of cultivation }\end{array}$} & $\begin{array}{l}\text { uproszczona } \\
\text { reduced }\end{array}$ & 82,2 & 81,5 & 85,9 & 14,0 & 7,0 & 10,5 \\
\hline & $\begin{array}{c}\text { tradycyjna } \\
\text { conventional }\end{array}$ & 81,5 & 92,0 & 86,7 & 12,5 & 3,3 & 7,9 \\
\hline \multicolumn{2}{|c|}{$\operatorname{NIR}(0,05)-\operatorname{LSD}(0.05)$} & r.n. & 2,371 & r.n. & 1,146 & 1,170 & 0,776 \\
\hline \multirow{3}{*}{$\begin{array}{l}\text { Ochrona } \\
\text { Protection }\end{array}$} & $\begin{array}{l}\text { kontrola } \\
\text { untreated }\end{array}$ & 81,5 & 91,3 & 86,4 & 14,7 & 4,0 & 9,4 \\
\hline & $\mathrm{T} 1$ & 82,2 & 90,7 & 86,4 & 14,2 & 5,2 & 9,7 \\
\hline & $\mathrm{T} 1, \mathrm{~T} 2, \mathrm{~T} 3$ & 82,1 & 90,4 & 86,2 & 10,7 & 6,2 & 8,4 \\
\hline \multicolumn{2}{|c|}{ NIR $(0,05)-\operatorname{LSD}(0.05)$} & r.n. & r.n. & r.n. & 1,921 & r.n. & r.n. \\
\hline
\end{tabular}

r.n. - różnice nieistotne statystycznie - not significant differences

Tabela 3. Procentowy udział gatunków rodzaju Fusarium zasiedlających ziarno pszenicy jarej

Table 3. Percentage share of Fusarium species infecting grain of spring wheat

\begin{tabular}{|c|c|c|c|c|c|c|c|c|c|c|c|c|c|c|}
\hline $\begin{array}{c}\text { System uprawy } \\
\text { The method } \\
\text { of cultivation }\end{array}$ & $\begin{array}{l}\text { Ochrona } \\
\text { Protection }\end{array}$ & \multicolumn{2}{|c|}{ 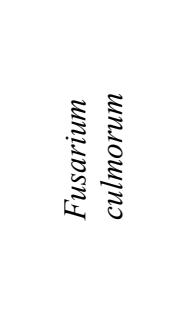 } & 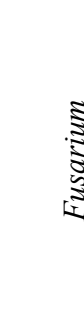 & $\begin{array}{l}\mathbb{8} \\
\vdots \\
2\end{array}$ & \multicolumn{2}{|c|}{ 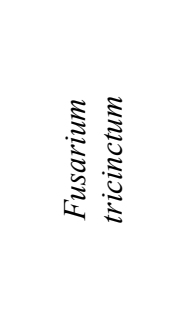 } & \multicolumn{2}{|c|}{ 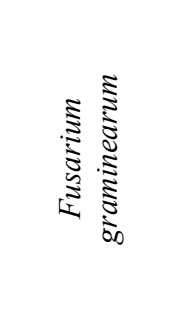 } & \multicolumn{2}{|c|}{ 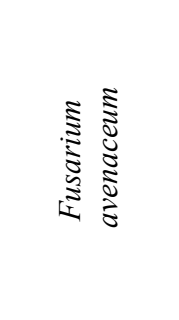 } & \multicolumn{2}{|c|}{ 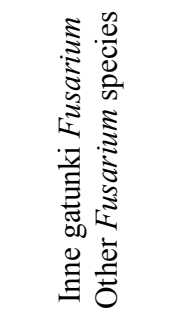 } & \multirow[t]{2}{*}{ 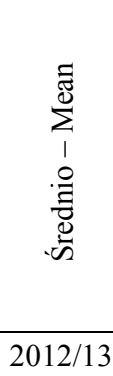 } \\
\hline \multicolumn{2}{|l|}{ Rok - Year } & 2012 & 2013 & 2012 & 2013 & 2012 & 2013 & 2012 & 2013 & 2012 & 2013 & 2012 & 2013 & \\
\hline 1 & 2 & 3 & 4 & 5 & 6 & 7 & 8 & 9 & 10 & 11 & 12 & 13 & 14 & 15 \\
\hline \multicolumn{15}{|c|}{ Przedplon - Forecrop } \\
\hline \multicolumn{15}{|c|}{ Pszenica - Wheat } \\
\hline \multirow{3}{*}{$\begin{array}{l}\text { Uproszczona } \\
\text { Reduced }\end{array}$} & $\begin{array}{c}\text { kontrola } \\
\text { untreated }\end{array}$ & - & - & - & - & - & - & - & - & 2 & - & 12 & - & 7 \\
\hline & $\mathrm{T} 1$ & 2 & - & - & 2 & 2 & 4 & - & - & 2 & - & 6 & - & 9 \\
\hline & $\mathrm{T} 1, \mathrm{~T} 2, \mathrm{~T} 3$ & - & - & 2 & 6 & 2 & 2 & 6 & - & - & - & - & - & 9 \\
\hline \multirow{3}{*}{$\begin{array}{l}\text { Tradycyjna } \\
\text { Conventional }\end{array}$} & $\begin{array}{l}\text { kontrola } \\
\text { untreated }\end{array}$ & - & - & - & 2 & - & - & 2 & - & - & - & 8 & - & 6 \\
\hline & $\mathrm{T} 1$ & - & - & - & 2 & - & - & - & - & - & - & 4 & - & 3 \\
\hline & $\mathrm{T} 1, \mathrm{~T} 2, \mathrm{~T} 3$ & - & - & - & - & 2 & 4 & - & - & - & - & 10 & - & 8 \\
\hline \multicolumn{15}{|c|}{ Kukurydza - Corn } \\
\hline \multirow{3}{*}{$\begin{array}{l}\text { Uproszczona } \\
\text { Reduced }\end{array}$} & $\begin{array}{l}\text { kontrola } \\
\text { untreated }\end{array}$ & - & - & - & 6 & 2 & 2 & - & - & - & - & 10 & - & 10 \\
\hline & $\mathrm{T} 1$ & 2 & - & 4 & 4 & - & - & - & - & - & - & 6 & 2 & 9 \\
\hline & $\mathrm{T} 1, \mathrm{~T} 2, \mathrm{~T} 3$ & 2 & 2 & - & - & 2 & - & - & - & - & - & 6 & 2 & 7 \\
\hline
\end{tabular}




\begin{tabular}{|c|c|c|c|c|c|c|c|c|c|c|c|c|c|c|}
\hline 1 & 2 & 3 & 4 & 5 & 6 & 7 & 8 & 9 & 10 & 11 & 12 & 13 & 14 & 15 \\
\hline \multirow{3}{*}{$\begin{array}{l}\text { Tradycyjna } \\
\text { Conventional }\end{array}$} & $\begin{array}{l}\text { kontrola } \\
\text { untreated }\end{array}$ & 2 & - & 6 & 2 & 2 & - & - & - & - & - & 8 & 2 & 11 \\
\hline & $\mathrm{T} 1$ & - & 2 & 2 & 2 & - & - & - & - & - & - & 4 & - & 5 \\
\hline & $\mathrm{T} 1, \mathrm{~T} 2, \mathrm{~T} 3$ & - & - & 2 & - & - & - & 4 & - & - & - & 4 & - & 5 \\
\hline \multicolumn{15}{|c|}{ Rzepak - Rape } \\
\hline \multirow{3}{*}{$\begin{array}{l}\text { Uproszczona } \\
\text { Reduced }\end{array}$} & $\begin{array}{l}\text { kontrola } \\
\text { untreated }\end{array}$ & - & - & - & - & - & - & - & - & - & - & 6 & - & 3 \\
\hline & $\mathrm{T} 1$ & - & - & - & - & - & - & - & - & - & - & 8 & 2 & 5 \\
\hline & $\mathrm{T} 1, \mathrm{~T} 2, \mathrm{~T} 3$ & - & - & - & 6 & - & 4 & - & - & - & - & 8 & - & 9 \\
\hline \multirow{3}{*}{$\begin{array}{l}\text { Tradycyjna } \\
\text { Conventional }\end{array}$} & $\begin{array}{l}\text { kontrola } \\
\text { untreated }\end{array}$ & - & - & 6 & - & - & - & - & - & - & - & 4 & 4 & 7 \\
\hline & $\mathrm{T} 1$ & - & - & - & - & - & - & - & - & - & - & 14 & - & 7 \\
\hline & $\mathrm{T} 1, \mathrm{~T} 2, \mathrm{~T} 3$ & - & - & 2 & - & 2 & - & - & - & - & - & 6 & 4 & 7 \\
\hline \multicolumn{15}{|c|}{ Burak - Beet } \\
\hline \multirow{3}{*}{$\begin{array}{l}\text { Uproszczona } \\
\text { Reduced }\end{array}$} & $\begin{array}{l}\text { kontrola } \\
\text { untreated }\end{array}$ & 4 & 2 & - & 2 & 4 & - & - & - & 2 & - & 14 & - & 14 \\
\hline & $\mathrm{T} 1$ & 2 & 2 & 8 & 4 & 10 & - & - & 2 & 2 & - & 12 & 2 & 22 \\
\hline & $\mathrm{T} 1, \mathrm{~T} 2, \mathrm{~T} 3$ & - & 6 & 8 & 6 & - & - & - & - & - & - & 4 & 4 & 14 \\
\hline \multirow{3}{*}{$\begin{array}{l}\text { Tradycyjna } \\
\text { Conventional }\end{array}$} & $\begin{array}{c}\text { kontrola } \\
\text { untreated }\end{array}$ & 8 & - & 6 & 6 & 4 & - & - & - & - & - & 6 & 2 & 16 \\
\hline & $\mathrm{T} 1$ & 6 & - & 12 & 2 & - & 2 & - & - & - & - & 6 & - & 14 \\
\hline & $\mathrm{T} 1, \mathrm{~T} 2, \mathrm{~T} 3$ & 2 & - & 4 & - & - & - & - & - & - & - & - & 2 & 4 \\
\hline
\end{tabular}

Tabela 4. Zawartość deoksyniwalenolu w ziarnie pszenicy jarej

Table 4. The content of deoxynivalenol in grain of spring wheat

\begin{tabular}{|c|c|c|c|c|c|c|}
\hline \multirow{4}{*}{$\begin{array}{l}\text { Sposób uprawy } \\
\text { The method } \\
\text { of cultivation }\end{array}$} & \multicolumn{3}{|c|}{ Rok - Year 2012} & \multicolumn{3}{|c|}{ Rok - Year 2013} \\
\hline & \multicolumn{3}{|c|}{ ochrona-protection } & \multicolumn{3}{|c|}{ ochrona - protection } \\
\hline & $\begin{array}{l}\text { kontrola } \\
\text { untreated }\end{array}$ & $\mathrm{T} 1$ & $\mathrm{~T} 1, \mathrm{~T} 2, \mathrm{~T} 3$ & $\begin{array}{l}\text { kontrola } \\
\text { untreated }\end{array}$ & $\mathrm{T} 1$ & $\mathrm{~T} 1, \mathrm{~T} 2, \mathrm{~T} 3$ \\
\hline & \multicolumn{3}{|c|}{ ppm } & \multicolumn{3}{|c|}{ ppb } \\
\hline \multicolumn{7}{|c|}{ Przedplon - Forecrop } \\
\hline \multicolumn{7}{|c|}{ Pszenica - Wheat } \\
\hline $\begin{array}{l}\text { Uproszczona } \\
\text { Reduced }\end{array}$ & 0,3 & 0,4 & 0,1 & 0,31 & 0,32 & 0,24 \\
\hline $\begin{array}{l}\text { Tradycyjna } \\
\text { Conventional }\end{array}$ & 0,1 & 0,1 & 0,0 & 0,85 & 0,49 & 0,43 \\
\hline \multicolumn{7}{|c|}{ Kukurydza - Corn } \\
\hline $\begin{array}{l}\text { Uproszczona } \\
\text { Reduced }\end{array}$ & 0,2 & 0,1 & 0,0 & 0,82 & 0,50 & 0,86 \\
\hline $\begin{array}{l}\text { Tradycyjna } \\
\text { Conventional }\end{array}$ & 0,2 & 0,1 & 0,0 & 0,55 & 0,53 & 0,31 \\
\hline \multicolumn{7}{|c|}{ Rzepak-Rape } \\
\hline $\begin{array}{l}\text { Uproszczona } \\
\text { Reduced }\end{array}$ & 0,0 & 0,0 & 0,0 & 0,16 & 0,51 & 0,51 \\
\hline $\begin{array}{l}\text { Tradycyjna } \\
\text { Conventional }\end{array}$ & 0,0 & 0,0 & 0,0 & 0,24 & 0,18 & 0,18 \\
\hline \multicolumn{7}{|c|}{ Burak-Beet } \\
\hline $\begin{array}{l}\text { Uproszczona } \\
\text { Reduced }\end{array}$ & 0,0 & 0,2 & 0,1 & 0,86 & 0,01 & 0,30 \\
\hline $\begin{array}{l}\text { Tradycyjna } \\
\text { Conventional }\end{array}$ & 0,1 & 0,0 & 0,0 & 0,10 & 0,11 & 0,15 \\
\hline
\end{tabular}


Zawartość deoksyniwalenolu oraz zearalenonu w badaniach własnych była niewielka i nie przekraczała dopuszczalnych przez UE norm. Jednak ze względu na dużą szkodliwość tych mikotoksyn istnieje potrzeba stałej kontroli ich zawartości. Wykonane analizy zawartości mikotoksyn wykazały w próbkach z 2012 roku znacznie większą zawartość DON w porównaniu z rokiem 2013. W obydwu latach zawartość DON okazała się niższa od dopuszczalnej przez UE (tab. 4). W 2012 roku w obu systemach uprawy pszenicy uprawianej po rzepaku nie wykryto w ziarnie pszenicy DON. Dla pozostałych przedplonów, zarówno przy uprawie uproszczonej, jak i tradycyjnej poziom DON wynosił od 0,0 do $0,4 \mathrm{ppm}$. W roku 2013 zawartość tej mikotoksyny wahała się pomiędzy 0,01-0,86 ppb. Występowanie deoksyniwalenolu stanowi istotny problem w warunkach epifitozy fuzariozy kłosów (Kryczyński i Weber 2011). W badaniach Kocha i wsp. (2006) określano wpływ przedplonu (pszenica i buraki cukrowe) oraz sposobu uprawy (orka głęboka, uprawa oraz siew bezpośredni) na zawartość DON. Autorzy zanotowali istotny wzrost zawartości DON $\mathrm{W}$ ziarnie pszenicy uprawianej po pszenicy w porównaniu $\mathrm{z}$ uprawą po buraku cukrowym. Istotnie mniej DON stwierdzono $\mathrm{w}$ ziarnie pszenicy pochodzącym $\mathrm{z}$ uprawy bezorkowej niż z pozostałych systemów uprawy. W badaniach własnych zawartość deoksyniwalenolu w ziarnie pszenicy jarej po zastosowaniu 3 fungicydów w trakcie wegetacji w 2012 roku ulegała redukcji w porównaniu z kombinacją kontrolną, z wyjątkiem pszenicy uprawianej po burakach $\mathrm{w}$ systemie uproszczonym. W drugim roku badań wykonanie trzech zabiegów $\mathrm{z}$ użyciem fungicydów wpłynęło na obniżenie zawartości DON tylko w uprawie pszenicy po pszenicy (system uproszczony i tradycyjny) oraz po rzepaku (system konwencjonalny). Wachowska i wsp. (2012) w badaniach nad skutecznościa działania tebukonazolu i tiofanatu metylowego w ograniczaniu fuzariozy kłosów stwierdziły w jednym z lat badań, przy dużej dynamice rozwoju fuzariozy kłosów, brak redukcyjnego wpływu na ogólną liczebność epifitycznych zbiorowisk grzybów rodzaju Fusarium. Gromadzka i wsp. (2012) w doświadczeniu z pszenicą ozimą, którą opryskiwano w fazie kłoszenia różnymi fungicydami, stwierdzili najmniejszą zawartość deoksyniwalenolu w kombinacjach, w których zastosowano protiokonazol + fluoksastrobinę oraz tebukonazol + protiokonazol.
Zawartość ZEA w ziarnie pszenicy zebranym w latach 2012 i 2013 była niewielka. W badanych próbach z 2012 roku stwierdzono ZEA w ilości od 0,2-11,5 ppb. W tym roku spośród kombinacji kontrolnych największy poziom ZEA notowano $\mathrm{W}$ ziarnie pszenicy uprawianej systemem tradycyjnym po burakach (11,5 ppb). Ilości ZEA uzyskane w 2013 roku kształtowały się na poziomie od 0 do 2,2 ppb. Wartości ZEA powyżej 0 stwierdzono w próbach pochodzących z roślin uprawianych po buraku oraz po pszenicy uprawianej systemem uproszczonym, w której w trakcie wegetacji wykonano 3 zabiegi przy użyciu fungicydów. Ma to związek $\mathrm{z}$ większym zasiedleniem ziarna przez grzyby rodzaju Fusarium pochodzącego $\mathrm{z}$ tych kombinacji. W doświadczeniu płodozmianowym przeprowadzonym w Niemczech autorzy zanotowali dwukrotny wzrost zawartości DON w ziarnie pszenicy uprawianej po buraku cukrowym oraz ziemniaku $\mathrm{w}$ porównaniu $\mathrm{z}$ uprawą pszenicy po zbożach, tj.: po jęczmieniu i pszenicy (Obst i wsp. 1997).

\section{Wnioski / Conclusions}

1. Zasiedlenie przez grzyby rodzaju Fusarium ziarna pszenicy jarej uprawianej po buraku było istotnie większe niż po rzepaku, pszenicy i kukurydzy.

2. Ziarno pszenicy uzyskane $\mathrm{w}$ uproszczonym systemie uprawy charakteryzowało się większym zasiedleniem przez grzyby patogeniczne rodzaju Fusarium, w porównaniu do ziarna pochodzącego $\mathrm{z}$ tradycyjnego systemu uprawy.

3. W obydwóch latach badań (2012 i 2013) jednokrotne zastosowanie fungicydu $\mathrm{w}$ terminie $\mathrm{T} 1$ nie wpłynęło na zmniejszenie występowania grzybów zasiedlających ziarniaki pszenicy jarej, a trzy zabiegi (T1, T2 i T3) istotnie ograniczyły jedynie w roku 2012 występowanie grzybów patogenicznych.

4. Z ziarna pszenicy jarej najczęściej izolowano: $F$. poae, $F$. tricinctum i $F$. culmorum.

5. Nie wykazano jednoznacznych zależności pomiędzy zawartością deoksyniwalenolu w ziarnie pszenicy jarej a przedplonem, systemem uprawy i stosowaną ochroną chemiczną.

\section{Literatura / References}

Bottalico A., Perrone G. 2002. Toxigenic Fusarium species and mycotoxins associated with head blight in small-grain cereals in Europe. European Journal of Plant Pathology 108: 611-624.

Christ D.S., Gödecke R., von Tiedemann A., Varrelmann M. 2011. Pathogenicity, symptom development, and mycotoxin formation in wheat by Fusarium species frequently isolated from sugar beet. Phytopathology 101 (11): 1338-1345.

Czaban J., Wróblewska B., Sułek A., Podolska G. 2011. Wpływ różnych technologii produkcji pszenicy ozimej na zasiedlenie jej ziarna przez grzyby z rodzaju Fusarium. Polish Journal of Agronomy 5: 11-20.

Gromadzka K., Lenc L., Sadowski C., Baturo-Ciesniewska A., Chełkowski J., Goliński P., Bocianowski J. 2012. Effects of fungicidal protection programs on the development of Fusarium head blight and the accumulation of mycotoxins in winter wheat. Cereal Research Communications 40 (4): 518-531.

Hecker A., Vogelgsang S., Wettstein F., Forrer H.R. 2009. Befalleiniger Winterweizensorten durch Fusarium-Arten. Agrarforschung 16: $244-249$.

Koch H.J., Pringas Ch., Maerlaender B. 2006. Evaluation of environmental and management effects on Fusarium head blight infection and deoxynivalenol concentration in the grain of winter wheat. European Journal of Agronomy 24: 357-366. 
Korbas M., Horoszkiewicz-Janka J., Jajor E. 2008. Uproszczone systemy uprawy a występowanie sprawców chorób. [Simplified systems of soil management in relation to the occurrence of disease casual agents]. Progress in Plant Protection/Postępy w Ochronie Roślin 48 (4): 1431-1438.

Kotowicz N.K., Frąc M., Lipiec J. 2014. The importance of Fusarium fungi in wheat cultivation - pathogenicity and mycotoxins production: a review. Journal of Animal \& Plant Sciences 21: 3326-3343.

Kryczyński S., Weber Z. 2011. Fitopatologia. PWRIL, Poznań, T. 2, 464 ss.

Lenc L. 2015. Fusarium head blight (FHB) and Fusarium populations in grain of winter wheat grown in different cultivation systems. Journal of Plant Protection Research 55 (1): 94-109.

Lenc L., Wyczling D., Sadowski Cz. 2009. Zasiedlenie ziarna pszenicy ozimej przez grzyby rodzaju Fusarium w zależności od przedplonu, uprawianej odmiany i stosowanych fungicydów. Ochrona Środowiska i Zasobów Naturalnych 41: 563-571.

Lienemann K. 2002. Auftreten von Fusarium-Arten an Winterweizen im Rheinland und Möglichkeiten der Befallskontrolle unter besonderer Berücksichtigung der Weizensorte. Ph.D. thesis. University of Bonn, Germany.

Mesterházy Á., Bartók T., Lamper C. 2003. Influence of wheat cultivar, species of Fusarium, and isolate aggressiveness on the efficacy of fungicides for control of Fusarium head blight. Plant Disease 87 (9): 1107-1115.

Obst A., Gleissenthall J.L., Beck R. 1997. On the etiology of Fusarium head blight of wheat in south Germany - preceding crops, weather conditions for inoculum production and head infection, proneness of the crop to infection and mycotoxin production. Cereal Research Communications 25: 699-703.

Popiel D., Kwaśna H., Chełkowski J., Stępień Ł., Laskowska M. 2008. Impact of selected antagonistic fungi on Fusarium species toxigenic cereal pathogens. Acta Mycologica 43 (1): 29-40.

Prodi A., Tonti S., Nipoti P., Pancaldi D., Pisi A. 2009. Identification of deoxynivalenol and nivalenol producing chemotypes of Fusarium graminearum isolates from durum wheat in a restricted area of Northern Italy. Journal of Plant Pathology 91: 727-731.

Rozporządzenie Komisji (WE) NR 1881/2006 z dnia 19 grudnia 2006 r. ustalające najwyższe dopuszczalne poziomy niektórych zanieczyszczeń w środkach spożywczych. Dz.U. UE L 364/5 z dnia 20 grudnia 2006.

Rozporządzenie Komisji (WE) NR 1126/2007 z dnia 28 września 2007 r. zmieniające rozporządzenie (WE) nr 1881/2006 ustalające najwyższe dopuszczalne poziomy niektórych zanieczyszczeń w środkach spożywczych w odniesieniu do toksyn Fusarium w kukurydzy i produktach z kukurydzy. Dz.U. UE L 255/14 z dnia 29 września 2007.

Stępień L., Chełkowski J. 2010. Fusarium head blight of wheat: pathogenic species and their mycotoxins. World Mycotoxin Journal 3: 107-119.

Wachowska U., Mikołajczyk W., Kucharska K. 2012. Skuteczność tebukonazolu i tiofanatu metylu w ograniczaniu rozwoju patogenów rodzaju Fusarium na kłosach pszenicy ozimej. [The effectiveness of tebuconazole and thiophanate-methyl in reducing the Fusarium pathogens development on winter wheat heads]. Progress in Plant Protection/Postępy w Ochronie Roślin 52 (3): 671-675. 